\title{
Partisans' and Civil Elites' Role in Supporting Military Coups: The Case of the Egyptian Elites
}

\author{
Mohammed T. Bani Salameh ${ }^{1}$, Mohammad Abdelrahman Banisalameh² \& Emad Shdouh ${ }^{3}$ \\ ${ }^{1}$ Political Science Department, Yarmouk University, Jordan \\ ${ }^{2}$ Humanities Department, Qatar University, Qatar \\ ${ }^{3}$ No Restrictions Center for Parliamentary Studies \\ Correspondence: Mohammed T. Bani Salameh, Political Science Department, Yarmouk University, Jordan. E-mail: \\ mohammedtorki@yahoo.com
}

Received: March 10, 2020

Accepted: August 1, $2020 \quad$ Online Published: August 17, 2020

doi:10.5539/jpl.v13n3p17

URL: https://doi.org/10.5539/jpl.v13n3p17

\begin{abstract}
The study reported in the article below tried to examine partisans' and civil elites' role in military interventions and coups. The 2013 Egyptian coup d'état that took place on 3 July 2013 was used as a model of analysis. Concisely, this study sought to identify the defining characteristics of the partisans and civil elites who supported that military coup in Egypt, including their social origins, their level of education, their views of democracy and constitutional legitimacy as well as the nature of their allegied tie-up with the armed forces. In order to do just this, the study used Samuel Huntington's hypothesis as a theoretical framework of analysis. Accordingly, elites' support for military coups underlies weakness (and therefore ineffectiveness) of the country's civil institutions as well as absence of institutional political channels that regulate competition and conflict between parties with differing interests and resources. An immediate outcome of such a state of affairs was that partisans and civil elites had demonstrated their superiority over the army as they possessed the means of power that enabled them to impose their control. The findings of the study showed that those partisans and civil elites, formed by mechanisms based on mutual interests and wealth, are only theoretically oriented in the sense that they only accept the principles of democracy and constitutional legitimacy in the event that they lead to their arrival to power. However, if that legitimacy comes from other political currents, (e.g. The Muslim Brotherhood), they soon turn against it.
\end{abstract}

Keywords: partisan and civil elites, military coup, social origins, civil institutions, legitimacy, power, and army

\section{Introduction}

The increasingly widespread political interference of military personnel in Third-World societies has stimulated the interest of researchers in social and political sciences as well as scholars in various fields of knowledge (such as language, anthropology, education, media, to mention but a few). By dedicating chapters in their publications about the subject matters, researchers try to study, analyze, and therefore interpret this phenomenon from their own scholarly theoretical perspectives. The interpretations of these interventions have ranged from one extreme (namely, acceptance of certain economic and political goals) to the other extreme (namely, refusal of the spread of this political interference with other economic and political interests).

The interpretations were generally influenced by two competing doctrines: militarism or "military rule" on the one hand and anti-militarism on the other. Whereas the former view advocates military coups as a driving force for political stability by preventing the disintegration of the political system, the latter maximizes the values of democracy and peaceful transfer of power (Mutter 1977). Be that as it may, we reckon that support of 'political stability' and 'economic development' as used by both parties is indeed no more than a thought-terminating cliché that would distract attention away from the underling lines of thought that each party tries to advocate.

However, the debate about the support of civil party elites for military interventions underlines the unbalanced distribution of power-sharing (whether horizontal or vertical) for political gains. What this means is that the motivating goal in the Egyptian case is not basically the sharing of power by the conversationalists on constitutional and legal grounds for the welfare of the homeland, but not missing a "slice of the cake", so to speak. This is probably so because the essence of this support is an undeclared pragmatic relationship in the form of civilian elites allied with the ruling military personnel (Madi 2012). 
While advocating the peaceful transfer of power through elections, the elite military regimes have condoned many dictatorial practices that amount to serious professional misconduct or even criminality in these societies. Quite expectedly, the military regimes have seized political power and consolidated it to the extent that they confiscated freedoms of various social and political forces, in some cases leading to the persecution of the elites that stood with them.

This study attempts to test Samuel Huntington's hypothesis that the support of civil and partisan elites for military coups underlies the weakness (and thus ineffectiveness) of the political institutions, including the political parties and civil society institutions, which are supposed to provide institutional channels to regulate competition (and therefore conflict) among the various components of society (Huntington 1977, 193-4). In the absence of this role, the army stands out as one of the most powerful components of society; hence they have the power to impose their control over the rest of the other components, including the ruling civil authority. A military coup is the means by which they can exercise their control and influence, not as institutionalized body but as one of the forces that reflects the political structure of society (Huntington 1957, 83). This view is paramount in the Egyptian case, especially during the period following the fall of Mubarak. The failure of the political elite - both the ruling class and the opposition - to reach a political consensus has resulted in the military bullying to resolve the political conflict by deposing President Morsi.

In this paper, we will try to address this issue by identifying the characteristics of the civil and partisan elites that supported the military coup in Egypt against President-elect Mohamed Morsi. The envisaged characteristics include their social origins, their level of education, their position on constitutional legitimacy and the nature of their relations with the armed forces. The paper is thus organized as follows. In section 2 below, we try to highlight the conventional and the procedural concept of the elite as well as the mechanism of forming political elites in the Egyptian context. In section 3, we will try to detail the intricacies of the Egyptian political scene at the time of the military coup against President-elect Mohamed Morsi. In the main body of the research in section 4, the characterizing features of the partisans and civil elites who allied with the military will be detailed. In section 5, the findings of the study will be discussed in light of the findings of previous research on the subject matter.

\subsection{Problem and Questions of the Study}

The problem of the study revolves around the answer to the two main intertwined questions: (1) "Would military intervention not have been possible" had it not been for the conflict between the political parties in Egypt? And (2) Are the ruling elites in the transitional stage of democratic transition not inclined to establish any liberal traditions that would allow them to continue the process of acquiring the economic surplus and thus reproduce the socioeconomic composition that ensures the prevailing class balances?

\subsection{Objectives of the Study}

The study aims to achieve the following objectives:

1) To know the political orientations of the civil and partisan elites that supported the military coup in Egypt.

2) To know the characteristics and features (e.g. social, educational and economic traits) of the civil and partisan elites that supported the military coup in Egypt who extracted political power from civilians.

3) To link their characteristics, features, social origins as well as level of education onto the constitutional legitimacy and the nature of relations with the armed forces.

\subsection{The Importance of the Study}

The study of political elites that supported the coup in Egypt is of great importance for the following reasons:

1) To understand the political and economic change that took place in the structure of the Egyptian state after the revolution in 2011.

2) To understand the nature of the distribution of power, authority and prestige of the actors in the decision-making process in the Egyptian political system.

3) To explain the causes of the conflicts among the Egyptian elites that impacted the structure and behavior of the various state institutions.

\subsection{The Hypothesis of the Study}

The study assumes that parties and personalities representing the interests of the armed forces, marginalized in the first post-transitional elections, are only willing to abandon the electoral process in favor of a conspiracy against democracy and stability. 


\section{Methodology of the Study}

The study has adopted the following approaches:

1) Elite approach: The elite approach dominated the theories of the transitional period (traditional and behavioral). Such theories maintained their vitality and methodological analytical capacity throughout the behavioral phase and beyond. Because there is no society without political, economic, cultural or mathematical elitism, the importance of the elite approach emerges as a framework for the study of comparative political systems.

2) Positions approach: The ruling political elites can be identified through the Functional Mean, where the elite is determined by occupying strategic positions in the political decision-making process and by enjoying great influence in the state and society. This approach considers that people who hold key positions in political, economic and military institutions are actually powerful and therefore influential in society (Barghouthi,2009).

3) Decision-making approach: This approach considers that everyone involved in political decision-making is an elite member, a direct indication of the political power of the elite. A criticism of this approach is that it limits the identification of important problems in most cases and neglects unimportant problems in society (Abu- Isba,1999).

4) Fame (reputation) approach: Elitism is determined through the knowledge of people known to possess the tools of power and influence in the state and society. This approach is only appropriate for the study of elitism in small or medium-sized communities. This approach tends to emphasize the apparent influence and relegates the importance of invisible influence (Haji,2002).

\section{Literature Review}

The study of the elite in any society is especially important as it contributes significantly to the understanding and interpretation of the structure of political power within the state. Like in any society, there is a limited ruling group that monopolizes the most important economic, social and political centers that play progressive roles within the political system and has powers at the decision-making level or the influence of its formulation and other largescale controlled which does not have the possibilities of making these decisions (Aledwan et al, 2018). Thus, in each community there is an elite that has the potential to play key and important roles in various areas. The concept appeared only on the political scene in the late nineteenth century (Shdouh,2017).

In the 1930s in Britain and America, in particular, the term was spread by the Italian political sociologist "Vilfedo Pereto" who considered the concept of the elite to reflect the fame and occupation of individuals and groups in the forefront. Elite analysis is a mechanism through which we understand the nature of the political system, the changes that may occur and the repercussions that affect the structure and composition of society, which all contribute significantly to understanding the nature of the distribution of power, authority and the actors in the decision-making process in society (Al-Manoufi,1985).

The writings of (Pareto, 1916), (Mosca, 1939) and (Brenham, 1941), (Raymond Aron, 1950) and (Robert Michels, 1962) all increase the levels of in-depth analysis of the political class in Western societies.

In the mid-1950s, (Wright Mills, 1950) transferred their scientific arguments about the organizational capacity of the elites to practical study. In his study the Power Elite, in American society, his findings indicate that a group of elites in US military and political institutions occupy an important place in decision-making. The membership of these elite groups is intertwined. They have positions of influence in various sectors. The results also indicate that these elites are socially homogeneous and interdependent groups in different sectors and share the same interests and values, which gives them the power of the elite influencing the majority.

In 1967, Oxford University Press published a collection, elite in Latin American countries. The results of the study indicate that Latin American societies are more traditional than Western societies and are still governed by a single elite, represented by the largest owners, the army and the Church, in contrast to modern Western societies which are dominated by more diverse and pluralistic economic, social and political structures (Lipset and Solar, 1967).

\subsection{The Concept of the Elite}

Elite theory is one of the political theories concerned with how elites are being formed in the society and how elites compete in seizing the key positions of the State. The theory also clearly explains the long-term persistence of the ruling class (Al-Aaly, M. 2007:69).

Studying the elites in a society is of paramount importance because it largely contributes to the understanding of the State's political regime structure and scheme. In any given society, there is always that small ruling group that monopolizes the key economic, social, and political positions; plays frontline roles within the political echelon, and possesses power or influence in the decision-making process. 
On the other hand, there is always the larger ruled group, with no such powers in decision making (Lekareny, I. 2007:51). In other words, in any society, an elite having the opportunity of undertaking major roles in various fields exists. Elite is a descriptive term for individuals and groups in certain hierarchical summits who possess the power sources and tools in the community.

The Concise Cambridge Dictionary defines the word "elite" as "the richest, most powerful, best educated or best trained group in a society". However, research on the concept has shown that it is both vague and ambiguous. The sources of vagueness and ambiguity are both linguistic and encyclopedic. To illustrate, the dictionary provides synonymous terms of the word elite such as ruling class, aristocracy, oligarchy and political class, each of which has its own meaning that makes it different from the others. World knowledge also makes it imperative that different people attribute different meanings to the word itself. Probably for this, we need to highlight in advance the conventional as well as the operational concepts of the term "elite" as used in this current study, a task we will attend to immediately.

Although the concept of 'elite' as a French term of Latin origin is conventionally used to denote all "chosen minority of the upper class who lead the political, cultural, or social scene", it is operationalized by Michelle Burton and John Higley (2001) into two types: central elites and secondary elites. Whereas the former group includes senior statesmen in their executive, legislative and judicial organs, the latter encompasses political, social, economic, religious, and media elites circulating in the orbit of the central elites (see Burton 2001, 182-191). These elites together make up a heterogeneous mix of official and civil elites, who often lead protests (or even revolutionary movements), thus participating directly or indirectly in the political decision-making process (see Bani Salameh and Shdouh 2017).

\subsubsection{Mechanism of Forming Political Elites in the Egyptian Context}

The Egyptian political discourse is a complex mixture of political systems ${ }^{1}$ based on the creation of conflicting mechanisms and strategies that ultimately bring abought the ruling political regime. However, these mechanisms go in two mirror-image directions. The first trend, characterized by extreme closures, forces position appointment to come from above, a practice that is dominated by the President of the Republic in first place and the prime ministries, general intelligence directors, and military leaders in second place. The second trend, characterized by openness and recruitment through democratic elections, requires elections and rising from the bottom, a process that involves members of the legislature, leaders of professional and labor unions, and leaders of civil society institutions.

In the last decade of Hosni Mubarak's rule, most of the regional as well as the internal political files were handed over to both the Egyptian Ministry of Interior and the General Intelligence Service. The latter has since played a dominant political role in the state and society in that it no longer restricts its activities to security or security control, but extends its hegemony to the civil society, including media institutions, universities, trade unions, workers, bankers, economists, and political parties. This policy is widespread in most Arab states, the Jordanian state, for example adopted a political discourse that led to the dominance and arrogance of security institutions and the rule of security discourse over aspects of life in the country. (Bani Salameh, 2017).

This hegemony has caused the formation of coalitions of senior members of the general intelligence services, the army, politicians, and influential media and businessmen, whose sole aim is to ensure the continuity of the ruling political elites through whom they can seize power. Their unpronounced agenda runs like this: on the one hand the senior leaders of the General Intelligence and the armed forces have internal alliances with civil society institutions dominated by political men responsible for the distribution of public goods from the state budget and its expenses; on the other hand as businessmen extend their financial and economic influence, media men undertake the task of polishing the image of all in front of the masses (Zaki, 2016) .

The political system also uses the strategy of containment and integration of partisan and civil elites opposed to the ruling regime, where the elites are organized and integrated into the institutions of the system, in order to support its political and economic tendencies and to play ideological roles that justify the policies of the regime. The integration (or containment) of these elites was often carried out within the umbrella of the regime's vision and orientation (i.e. directly linked to the system's inputs and outputs). It is based on sharing roles, tasks, and positions among these elites. When objecting to the regime's policies and agendas, they were pushed outside the political elites ruling circles and/or even prosecuted.

\footnotetext{
${ }^{1}$ The Egyptian regime mixes the absolute autocratic system and the semi-democratic, which is based on the social status of the elites and plutocrats and the gate of wealth and richness of the elite and oligarchy, the rule of oligarchs or the few that owns wealth.
} 
This policy has led to the emergence of cronyism and nepotism around the President of the Republic, the prime ministries, army commanders, and directors of the General Intelligence. the advent of any party to power entails re-distribution of positions and a sizeable portion of their riches among members, including relatives, in-laws and their friends, giving them funds for economic projects such as granting commercial agencies, redistributing state lands and residential or agricultural units, etc. Through tax and customs exemptions and tax evasion, they have grown over time to a wealthy political class possessing many real estate holdings, farms, commercial agencies, shares in companies, and huge funds in national and international banks.

\subsection{The Political Environment of the Egyptian Political System}

Egyptians have lived under military rule for almost sixty years now. The first coup occurred on July 23, 1952 when the Free Officers overthrew the Monarchy. When fellow coup leader, Gamal Abdel Nasser, and his comrades felt that Muhammad Najib, the coup leader, wanted to hand power over to the civilians, Nasser carried out a military coup against him. Nasser was immediately crowned president of Egypt until his death in 1969. Power was handed over to another military officer, Anwar Sadat who was then the vice-president of Gamal Abdel Nasser. Upon his assassination in 1982, Mubarak became president of Egypt until his stepping down and handing power to an army council on 25 January 2011 due to anti-government demonstrations, apparently encouraged by Tunisian street protests in the so-called 'Arab Spring' (Bani Salameh, 2013).

All successive political regimes sought to create their own elite circle at the expense of the circles of the former systems. This is often achieved by consolidating the interests of its own members through building alliances among them According to Bentam's law, "The higher the elite becomes, the more similar social characteristics become within it" (See Ahmed 2013). This was done by Nasser with his military elite, by Sadat with a double elite between the military and the media, and by Mubarak with an elite that combined the military and businessmen who still hold more than $95 \%$ of the Egyptian people's capabilities. However, Al-Sisi's elite circle is an assortment (or even hodgepodge) mix of judges, party leaders, businessmen, journalists, and clerics.

When President Hosni Mubarak left office, the state institutions were fragile, troubled and unstable as most of the bureaucratic apparatuses were suffering from weak rule of law and pervasive corruption. This was evident by the declining role of the social state and the regional status of the Egyptian state as well as the tyranny of the security state and the closure of the horizon of political reform. All these factors were crucial in the January 25, 2011, the military-backed revolution (Suleiman 2016, 48).

The leaders of the army, and those who benefited from the army's stay in power, ended its rule in favor of an Islamic regime. Therefore, an appropriate political and popular atmosphere was created to make Abdel Fattah alSisi lead a bloody coup d'état that would bring Egypt back to the pre-revolutionary era. The fall of the Brotherhood's rule in Egypt has its direct impact on the relationship between the Brotherhood and the state in many other Arab countries including Jordan, Saudi Arabia, and United Arab Emirates (Bani Salameh, 2019, a).

The seizure of political power by military leaders was then justified on two major grounds. First, the former regime (the Brotherhood) had betrayed their national and social responsibility. Second, the army is the only institution that could then serve the people (not the government or the regime). Mottos such as remove "the villains who hold power, clean the country of corruption, tyranny, selfish interests" were very alluding to the public at the time. With the abolition of the constitution, the arrest of the president and members of the government, the dissolution of parliament and the imposition of martial law, the army put an end to the pseudo-democracy used by the Muslim Brotherhood and others to reach and stay in power and thus encroach on the laws (Arnold 2004, 11).

\subsection{Egyptian Party Elites That Supported the Coup}

Depending upon the nature of their dealings with the military intervention in political life, the Egyptian party elites can be classified into three main streams. These are liberal and leftist elites, religious elites, and Media elites. In the next subsection, we turn our attention to detail the characterizing features of each stream.

\subsubsection{The First Stream: Liberal and Leftist Elites}

These elites based their argument on the idea that it is best to have authoritarian not Islamic regimes, and that the Muslim Brotherhood, in particular, is the source of scourge, extremism, and terrorism (See Abbas 2007). As the concept of atonement is an essential component of the structure of religious discourse, both moderate and extremist, these liberal and left-wing elites consider Islamic thought to be an underdeveloped theory that could only pull the state back to the Middle Ages, where the practice of religious values is their top priority (see, for example, Hamdan 2015, 65; Yousef 2015, 85). Dealing with President-elect Mohamed Morsi on the basis of this argument, these elites (supporting the coup) presented power politics to the ideological front. In simple terms, they use ideological and sectarian contradictions to a great extent to justify (and probably legitimize) the coup d'état (Asburg, Haiku 
Feyman 2016). Many pro-democracy elite members left the country to Europe and United States in search for freedom and dignity (Bani Salameh, 2019,b).

At the level of detail we are considering here, we reckon (on political reality) that the elites of the left and the liberals are more theoretical than real, in the sense that they accept the principles of secularism which is based on a modern, democratic, civil state in which the people are the source of authority and respect for human rights in the event of their arrival to power. However, in the case of the arrival of other political ideologies to power, they do not accept them and soon turn against them (Mustafa 2012).

In the first statement of the declaration of formation of the Egyptian Salvation Front, which included most of the symbols of the liberal and leftist movement ${ }^{2}$, they authorized the military leaders to overthrow President-elect Mohamed Morsi, declaring immediately that "The rescue of Egypt from the coming destruction will come only from the unity of the army and the people, including the political and military leaders and the establishment of a civil state protected by the army"; otherwise, their argument goes, "Egypt will collapse and we will regret the days before the announcement of the new constitution and considered peaceful public demonstrations a national duty that is necessary until the army responds and declares its support for the people." ${ }^{3}$

The leaders of the Front (Mohamed Elbaradei, Hamdine Sabbahi, Amr Moussa, Mohamed Aboul Ghar) accused President-elect Mohamed Morsi of turning his back to the democratic principles upon which the revolution was sparked off. Believing that Morsi's rule has lost political and legal legitimacy, they demanded the intervention of the armed forces and Western countries to save the revolution from the rule of the Brotherhood.

These left-wing and liberal Egyptian forces also established and supported the so-called rebellion movement with the sole aim of collecting a delegation to call upon the army to take the lead to overthrow the elected president. The movement, according to its claim, managed to collect 22 million signatures to withdraw confidence from President-elect Mohamed Morsi (Hamzawy and Den 2017, 8). The Free Egyptians Party funded most of the armed demonstrations that took place during President Mohamed Morsi's rule. ${ }^{4}$

The army carried out its coup on July 3, 2013. The president-elect was immediately arrested after being removed from power by the army, a move that was publicly blessed by the clerics of the Al-Azhar Foundation and the Pope of the Coptic Church and openly supported by the symbols of the parties and the liberal and leftist movement leaders. The People's Assembly was dissolved, and the 2012 Constitution was abolished. The President of the Supreme Court was appointed as interim President of the Egyptian State, deputized by the Secretary General of the Salvation Front (El Sherif 2014). The elites were quick to agree to hold government posts and to participate in the founding committee which undertook the responsibility to draft a new constitution. ${ }^{5}$ The issuance of new constitution or amending the valid constitution became a wide spread phenomenon in most Arab Spring countries to achieve the desired political reform and the development of political life. (Bani Salameh and Ananzah,2015).

As a betrayal to the democratic principles of the revolution, the fast-running events at the time proved unequivocal that the coup was carried out with secular blessing form the elites, whose ubiquitous logos of a faithful leader turned to be no more than lip service to the idea (Al-Sayed 2015,35-45). Table 1 below shows some characterizing features of the liberal and left-wing political elite figures who lead the support of the coup.

\footnotetext{
${ }^{2}$ The list included 35 political parties and a political and revolutionary movement, all of which had liberal and leftist ideologies. At the beginning of its establishment, they called for the repeal of the constitutional declaration issued by President Mursi, and then called for the intervention of the army in politics and the overthrow of the Islamists and supported the coup. The most prominent symbols were Hamdin Sabahi, Mohamed ElBaradei, Amr Moussa, Mohamed Elbaradei, Mohamed Abu Ghar, Osama Ghazali Harb, Hazem Beblawi

${ }^{3}$ El-Baradei, Moussa and Sabahi announced the establishment of a national rescue front, the Arab on 24 November 2012

${ }^{4}$ One of the most prominent figures is Naguib Sawiris, a prominent Coptic businessman who enjoys the support of the Coptic Church and businessmen.

${ }^{5}$ The list of government members associated with liberal and leftist political parties that supported the January 25, 2014 coup, Mohamed Elbaradei, Vice President, resigned in protest at the dissolution of the Brotherhood's sit-ins on 14 August; The list also included Prime Minister Hazem Beblawi, Minister of Labor Kamal Abu Eita, Minister of Social Solidarity Ahmad Al-Borai and Minister of Higher Education Hossam Issa, and Mohammed Abu al-Ghar, secretary-general of the Social Democratic Party.
} 
Table 1. Characteristics and features of the liberal and leftist political elites of Egypt

\begin{tabular}{|c|c|c|c|c|c|}
\hline Original Job & Educational level & Social Origin & $\begin{array}{l}\text { Political } \\
\text { Orientation }\end{array}$ & Position & Name \\
\hline International Organization & $\mathrm{Ph} . \mathrm{D}$ & Upper class & liberal & $\begin{array}{l}\text { Interim } \\
\text { President }\end{array}$ & Mohamed El Baradei \\
\hline Private sector & $\mathrm{Ph} . \mathrm{D}$ & Upper class & Liberal & Prime minister & Hazem Beblawi \\
\hline $\begin{array}{l}\text { Political part leader and owner } \\
\text { of satellite channel }\end{array}$ & B.A & Upper class & Liberal & Business man & Hamdin Sabahi, \\
\hline Private sector & B.A & Upper class & Liberal & Deputy prime minister & Ziad Bah Eldin \\
\hline Private sector & B.A & Upper class & Leftist & - & Ahmad Al-Borai \\
\hline Private sector & B.A & Upper class & Leftist & - & Hossam Issa \\
\hline Private sector & B.A & Upper class & Leftist & - & Kamal Abu Eita \\
\hline $\begin{array}{l}\text { General Secretary of Arab } \\
\text { League }\end{array}$ & B.A & Upper class & Nationalist & - & Amr Moussa \\
\hline Private sector & B.A & Upper class & Leftist & Minister & Mohamed Abu Ghar \\
\hline Private sector & B.A & Upper class & Leftist & - & Mosama Ghazali \\
\hline
\end{tabular}

Source: prepared by the researchers

A swift look at the table would immediately show that most of the leaders of the leftist and liberal Egyptian parties have emerged from the bureaucratic corps of the Egyptian state; many of whom had been active in the traditional structures of the Egyptian society - clans and extended families - some businessmen who aspired to play a political role parallel to their economic role. And the lists of these parties included figures who were aspiring to return to leadership positions, their Paradise Lost ${ }^{6}$.

As most of these Egyptian parties had failed to achieve the slogans they had raised due to their dim presence in the life of society, ${ }^{7}$ their leaders chose momentary transformation from open channels (such as representative institutions of political framing, socialization, and crystallization of demands) to closed channels where transparency and democratic practice were absent. What this means is that elites' interests are only seasonal as they are always evoked by the prevailing discourse, thus relegating their role in political action to a desk job. ${ }^{8}$

As a result, their role in the latest military coup has stressed their undeclared historical relationship with the thenin-power political authority, a relationship which was mainly based on the centrality of opposing alliances through the development and encouragement of pro-state elites on the one hand and the marginalization and fragmentation of opposition political elites on the other (Abdullah 2010). While working in conjunction, they never hesitated to support the creation of legislations and laws that reinforce this approach ${ }^{9}$

\subsubsection{The Second Trend: Religious Elites}

The concept 'religious elite' is often used to refer to those who enjoy a distinct degree of religious authority such as the members of Al-Azhar Foundation or the Coptic Church. Viewing a rising population as a threat to their dominance, religious elites use fatwas, judiciary and educational influences to control the masses by creating exoteric practices for the masses while embracing esoteric meanings that only enlighten middle-class people are

\footnotetext{
${ }^{6}$ Among them, we find prominent figures including, but not limited to, the former Secretary of State and the former Secretary of the League of Arab States Amer Musa, former Prime Minister Ahmed Shafiq, the former Prime Minister under Mubarak and the former candidate for the presidency, Mohamed ElBaradei, Secretary-General of the Nuclear Energy Organization

${ }^{7}$ Since the fall of the rule of Hosni Mubarak until the date of the military coup, there have been five electoral democratic processes, fair and transparent. All electoral entitlements, most of them under the junta, showed the power of the Islamic trend and its supporters to amend the constitution on two occasions, and gave them a majority in the People's Assembly and Shura Council, and culminated in the victory of Mohamed Morsi presidency. For more details, see Basim Jalal al-Qasem and Rabea Muhammad al-Danan (2016).

${ }^{8}$ The number of Egyptian parties parties in 2013 were (78), then rose to (83) parties in 2017. For details, see the following website: http://www.eip.gov.eg/Directories/Directory.aspx?id=56

${ }^{9}$ The military used a ruling issued by the Constitutional Court to dissolve the People's Assembly six months after it was held in 2012 . The military also issued a constitutional declaration that made all the threads of the political game in his hand. The military rule also issued an electoral law in 2015 that excluded all opposition parties from having access to parliamentary seats.
} 
able to understand. By preserving their religious authority, they can exercise their influence over other groups mainly to maintain their common interests and roles (Hazri 2013, 56). A close scrutiny of the Egyptian religious elite division order, one can attest it has diverged into at least three different directions: the official trend, the political trend and the rhetoric trend.

\subsubsection{The Official Trend: The Al-Azhar Foundation and the Coptic Church}

\section{- Al-Azhar Foundation}

Al-Azhar Foundation has been exercising many social and cultural roles as a religious and educational institution. Egyptians have been always waiting for the opinion and religious pronouncements of Sheikh of Al-Azhar, as the head of the highest religious institution in Egypt, on controversial social, political and religious concerns. The first official statement issued by Al-Azhar during the revolution was the implicit support of the political system, thus religiously outlawing demonstrations against state institutions as they threaten the country's political and social stability(Al-Bassiouni2011)

Probably, the undeclared cause of this support was that the election of President Mohamed Morsi would be a real threat to al-Azhar, and its Sheikh, fearing that the Muslim Brotherhood (as a religious a movement) would rival the influence of the "exclusive religious discourse" that the Al-Azhar religious institution always took (Morsi and Brown 2013).

The statement by Sheikh Ahmed al-Tayeb, who was a member of the ruling National Democratic Party's policy committee, to the Egyptian people was issued on 3 July. It openly justified the army's decision to overthrow the elected president. The argument was like this: Islamic law says that commitment to the 'lesser of two evils' is legitimate. The same argument followed the path already undertaken by Ali Juma'a, "The Mufti of the Egyptian Republic, where he ruled that it is permissible to kill opponents of the military coup on the grounds that they are outlaws" (Morsi and Brown 2013).

\section{- Coptic Church}

The three Coptic Orthodox, Catholic, and Evangelical communities rejected calls to take part in the demonstrations and protests of the $25^{\text {th }}$ of July. The Church justified their decision on the grounds of not knowing the real objectives of the demonstrators and/or the details of the protest plans. The Church called upon its followers not to accept invitations nor participate in demonstrations calling for sabotage and destruction. The priest of the Church of the Holy Virgin Mary sent out a call on January 19 to pray to God in churches or homes to save Egypt and its people.

\subsubsection{The Political Trend: Salafist Nur Party}

Supported by some of the Gulf states, especially Saudi Arabia, the Salafist Nur Party stood firm with the military coup leaders, though the religious literature of the Nur Salafist party forbids going against the ruler. Ironically, as "actions speak louder than words", Salafists proved to be not abiding by their religious convictions which they had been preaching for decades. In a nutshell, they followed neither the spirit nor the letter of the religious law they had been preaching for decades.

By forming coalition with Salafists, the army, the rebels and the opposition parties added faces with beards to the scene of the coup, thus coloring their move with some religious flavor. Table 2 below shows the characteristics and features of the Egyptian religious elites who supported the coup.

Table 2. The characteristics and features of the Egyptian religious elites who supported the coup

\begin{tabular}{llllll}
\hline Job origin & Educational level & Social origin & political orientation & position & Name \\
\hline Public Sector & Ph.D & Middle Class & Islamic & Sheikh Al Azhar & Ahmed al-Tayeb \\
Public Sector & B.A & Middle Class & Islamic & Mufti of the Ali Juma'a & Republic \\
Private Sector & B.A & Upper Class & Christian & Coptic Pop & Pop Twadross II \\
Private Sector & B.A & Middle Class & Salafi Muslim & Chairman of the Yones Makhyoun \\
\hline
\end{tabular}

Source: prepared by the researchers 


\subsubsection{Third Trend: Media Elites}

While electronic media had enabled widespread solidarity and rapid mobilization during protest movements against Mubarak's regime, they had also been effective means of polarization during Morsi's rule, enriching hostile attitudes against the Brotherhood Movement in general and President Morsi in particular. They were exploited by the old elite circles as a political resource against their target rivals. Since Mohamed Morsi took over the presidency, he soon became the target of the official and private media owned and/or run by these elites.

Private channels owned by businessmen associated with Mubarak were already filled with phrases such as "state bunkers", "Muslim Brotherhood militias," etc. Likewise, state-owned media (e.g. television channels, radio stations, newspapers, and websites) had been participating in the campaigns which aimed to demonize the Muslim Brotherhood movement under the umbrella of freedom ${ }^{10}$.

During the time of Morsi's rule, the non-allied Egyptian media counted on three main strategies to demonize the President and his party. These are: challenging his legitimacy, challenging his patriotism and nationalism, equating President Morsi with ex-president Mubarak, and likening the Brotherhood Party to the National Democratic Party (NDP).

Responding to Sisi's call for support to authorize him to confront what he called "terrorism", twenty-eight private and state-run Egyptian channels were covering the activities of the demonstrations calling upon president Morsi to step down. These channels cancelled their already-scheduled programs to focus instead on the events of those demonstration, favoring positive portrayals of the military over coverage of the then-President Morsi.

After the coup d'état, calls for disbanding supporters of President Morsi's return intensified. The official and private media adopted campaigns to demonize protesters in Rabah and Nahda fields, sometimes describing them as mentally retarded, sometimes as armed terrorists, and sometimes as criminal murderers. The sit-in of the massacre was the worst in Egypt's modern history. Yet, the Egyptian media tried to portray Sisi's move as a national achievement, carried out by Fedayeen and heroes (Al-Danan 2016).

Table 3. Characteristics and features of Egyptian media elites

\begin{tabular}{llllll}
\hline Job Origin & Educational Level & Social origin & political Orientation & Satellite Channel & Name \\
\hline Private Sector & B.A & Upper Class & Liberal & CBC & Emad Eldeen Adeeb \\
Private Sector & B.A & Upper Class & Liberal & Al-Nehar & Amro Adeeb \\
Private Sector & B.A & Upper Class & Liberal & Cairo and the People Lamees Al Hadeedi \\
Private Sector & B.A & Upper Class & Liberal & Echo of the Country Ahmed Mousa \\
Private Sector & B.A & Upper Class & Liberal & Cairo & Mahmoud Saed \\
Private Sector & B.A & Upper Class & Liberal & Almehwaer & Muna Al Shadeli \\
Private Sector & B.A & Middle Class & Liberal & Axes & Wael Al-Abrashi \\
\hline
\end{tabular}

Source: prepared by the researchers

\subsection{Characteristics of Trade Union Elites and Egyptian Civil Society Institutions}

The trade union elites and the elites of Egyptian civil society institutions were moved by the same social, ideological and political principles of the parties they were members of. The performance of these unions had been highly politicized. ${ }^{11}$ Therefore, ideological differences among them had continued to overshadow these forces and thus weaken their ability to unite behind specific and clear demands. For this, agreement between them on all the controversial political issues in the Egyptian context was far from being complete.

\footnotetext{
${ }^{10}$ The network "dream" space was owned by businessman Ahmed Bahgat, and network "axis" was owned by businessman Hassan Rateb. The channel is owned by businessman Naguib Sawiris, who also owns the channel "cbc". The channel "Al-Nahar" was owned by the businessman Mohammed Amin. The channels of the echo of the country was owned by businessman Mohammed Abu Al-Enein; and Mr. Al-Badawi heads the board of directors of "Al-Hayat". Business Tarek Nour owns Cairo and people channel. See Ahmad Talawi, (2016) on the following link: http://www.eipss

${ }^{11}$ Wafd party had had alliance with the Muslim Brotherhood in the 2011 parliamentary elections, with a number of small secular and religious parties, but the dispute between the Wafd Party and the Muslim Brotherhood about the number of seats for each party and the role of religion in politics led to the withdrawal of the Wafd Party from the coalition
} 
These elites were characterized by their lack of autonomy in decision-making and/or survival in power, a state of affairs that had negatively affected their political or economic position. Beginning the search for new political, economic, or social bodies to contain them (and ultimately their survival within the framework of the elite) depended on their ability to positively adapt to the demands of the authority and/or successfully face the pressures exerted on them (McCoy and Stroupem 2001, 247-264). These elites (partisan, trade union, and elite of Egyptian civil society organizations) often had utilitarian slogans, still chanted for mutual interest and wealth (Zahran 2007).

Compared to the other elite groups, the common characteristics of trade union elites and Egyptian civil society institutions are two: (1) common perceptions and vision, and (2) social alliances, features we will attend to immediately (Sayegh 2012).

\subsubsection{Common Perceptions and Visions}

These elites share the common view that 'protection of the homeland' is a top priority. However, their machinery for defending homeland is removing 'opponents' from the front. The arguments they propagated included: Islamists are dark reactionaries who have kidnapped the nation, the people are not as yet qualified for democracy, and the military and the people united in face of the 'opponent'.

\subsubsection{Social Alliances}

In order to form coalitions of military bureaucracy and civil elites, trade union and Egyptian civil society elites had intertwined with top figures of the existing political organization and a group of cultural and media and businessmen. These alliances were supported by proportional relations, partnerships, and broad commercial partnerships. To implement economic, political, social, and cultural system policies, these alliances represented an intermediate layer between the regime at one end of the scale and the people at the other.

\subsubsection{Media, Religious Discourse, and Authority}

The deep state in Egypt had been able to build deep-rooted alliances of dominant political parties, religious authorities, and media and business forces, all working in tandem to consolidate the pattern of the political regime that could, at least momentarily, maximize gains for them and minimize cost on them. Media, in large part, turned into the voice of the regime, resonating the interests of a group of media professionals, the heart of which was business owners of space stations. In the religious discourse, the alliance with institutions of faiths and religious symbols has produced a formative religious discourse that strongly supported the ruling authority by prohibiting disobedience or opposition to the authority. As Prester, and Altosir (2014) say, if the state has one repressive apparatus that is divided into security and military institutions (police, courts, prisons, etc.), it has various ideological apparatuses such as the religious apparatus (mosque and church), the educational apparatus (the school and the university), the media (radio, television, newspapers), and the political apparatus (political system). All of which the State produces and reproduces its speech, through the functions of these various devices.

These characteristics and features could, we reckon, show one fact: the reciprocal relationship between authority and elites is a benefit-cost trade-off. In exchange for loyalty and support, the political authority remained the supreme hand for all symbolic and material gifts and gains bestowed upon those elites through a symbolic contract mechanism that illustrated mutual benefits (Al-Otri 2012).

\section{Conclusion}

The Egyptian military has been playing a decisive role in national politics since the revolution in 1952, when a military coup led by a group of young officers brought down the monarch, King Farouk, and expelled out the British. With the eruption of the Arab Spring revolutions in 2010, the military institution played a leading role in controlling the course of events in all Arab Spring Countries, Egypt is not an exception. The Supreme Council of Armed Forces (SCAF)governed the country from February 2011 until June 2012. They did not cooperate with the elected civilian President Morsi of the Muslim Brothers. In June 2013, the Defense Minster General Abdul Fatah Elsisi led a military coup against president Mohammad Morsi, the first civilian elected president in the history of Egypt. Later on, Elsisi became the president of Egypt through presidential elections which were neither fair nor free. Since then up to this time, all state and society institutions have been militarized to serve the interest of the regime, this includes the political elite, political parties, the parliament, the judiciary, the media, the economy and even the military institution.

The Egyptian political discourse is a complex mixture of political systems, with conflicting positions and strategies. However, it has one characterizing feature, namely the production of a circle of elites through the appointment of the President of the Republic, directors of the General Intelligence, and army commanders. The one main goal of the coalition was to ensure the control and continuity of the ruling political elites consisting of senior members of 
the General Intelligence Service and the army whose interests intertwined with the interests of merchants, traditional and nouveau-riche businessmen, landowners, high ordained priests and sheikhs as well as media professionals.

Although the revolution of July 25, 2011 caused the president to step down, the political class formed during his reign remained active in the political and security scene. With the arrival of President Mohamed Morsi of the Muslim Brotherhood, they formed coalitions (of the General Intelligence Service, the army, politicians along with religious, media and businessmen) to act as a counterweight. Accusing Morsi of incompetency to govern and of betrayal to his national and social duties, they demanded that the army commander seize political power. However, the reciprocal relationship between all parties involved in the Egyptian political discourse which is based on a cost-effect trade-off has brought power politics to the ideological front.

\section{References}

Abbas, F. (2007). Terror industry in the history of the Muslim Brotherhood. Urban Dialogue. Retrieved December 22, 2015, from www.ahewar.org/debat/show.art.asp?aid=116292

Abdullah, N. (2010). Comparison between Egypt and Poland. Journal of Democracy, 24(240). Retrieved June 1, 2018, from http://democracy.ahram.org.eg/News/142.aspx

Abu-Isba, B. (1999). The Political Elite of Yemen (1987/1990). Madbouli Library, p. 38.

Ahmed, Z. (2013). The post-colonial era. Journal of Democracy, 23(5).

Al-Aaly, M. (2007). Moroccan Parliamentary Elites. Democracy Magazine, Al-Ahram Institution, Cairo, (25).

al-Bassiouni, R. (2011). Behind the scene of the Revolution. Cairo, EG: Dar Al-Farouk for Cultural Investments.

al-Danan, R. M. (2016). Egypt between two covenants: Mursi and Al-Sisi: A comparative study, The evolution of Egyptian media performance since the Revolution of 25 January to the end of 2015. Zaytouna Center for Studies and Consultations, Beirut. Retrieved September, 22, 2017, from https://www.alzaytouna.net/2016/07/14

Aledwan, et al. (2018). Elite Circulation Case Study of the Jordanian Parliament. Dirasat, Human and Social Sciences, 45(4). Retrieved from https://dirasat.ju.edu.jo/HSS/Article/FullText/13819?volume $=45 \&$ issue $=4$

Al-Manoufi, K. (1985). Theories of Political Systems. Publishing Press Agency, p. 51.

Al-Otri, A. R. (2012). Theology of the Aged: Mechanisms of Production of Political Integrity (3rd ed.). Rabat.

Al-Qasemm, B. J., \& Al-Danan, R. M. (2016). Egypt between the two pillars of Mursi and Sisi: a comparative study. Center for Studies and Consultations. Retrieved June 11, 2017, from http://www.alzaytouna.net/wpcontent/plugins/extrawatch-pro/components/com_extrawatch/extrawatch.php?origin

Al-Sayed, R. (2015). Community, Society and the State: The Authority of Ideology in the Arab-Islamic Political Field. Jadawel li atwzee' wa anasher. Retrieved December, 25, 2017, from https://www.neelwafurat.com/itempage.aspx?id=lbb243746-224694\&search

Amos, P. M. (1977). The Military and Politics in the Modern Times. New Haven and London: Yale University Press.

Arnold, L. (2004). Security sector reform in the Arab Middle east: A Nascent debate, in Alan Boyden and heiner Hanggieds. Reform and reconstruction of the security sector, Yearbook 2. The Geneva Centre for the democratic control of Armed Forces.

Aron, R. (1950). Currents in Sociological Thoughts (Vol. 2). Routledge Classics.

Asburg, M., \& Feyman, H. (2016). Western Perspective, The bitter harvest of the Arab Spring: Transformations of elites and new social mobility.

Bani Salameh, M. (2013). Al-Hirāk al-Shabābi al-Urduni fi Zal al-Rabi 'a al- Arabi. Amman: Markaz al-Badil.

Bani Salameh, M. T. (2019). Migration from the Arab Spring Countries to Europe: Causes and Consequences. In A. Al-Masri, \& K. Curran (Eds.), Smart Technologies and Innovation for a Sustainable Future. Advances in Science, Technology \& Innovation (IEREK Interdisciplinary Series for Sustainable Development). Springer, Cham. https://doi.org/10.1007/978-3-030-01659-3_28

Bani Salameh, M. T., \& Shdouh, E. (2018). Feminist Elites in Democratic Jordan 1989-2016. Environment, Politics, and Society (Research in Political Sociology, Vol. 25), Emerald Publishing Limited, pp. 181-201. https://doi.org/10.1108/S0895-993520180000025010 
Bani Salameh, M. T., \& Ali Ananzah, A. (2015). Constitutional Reforms in Jordan: A Critical Analysis. Digest of Middle East Studies, 24, 139-160.

Barghouthi, S. (2009). Characteristics of the Palestinian political elite before and after the establishment of the Palestinian National Authority, Zaytouna Center. Studies and Consultations: Beirut, p. 25.

Benham, J. (1941). The Managerial Revolution: What is Happening in the World. New York: John Day Co; p. 29.

Burton, M., \& Higley, J. (2001). The Study of Political Transformation. International Review of Sociology, 11(2), 182-191.

El Sherif, A. (2014). Egypt's post-Mubarak impasse. Carnegie Endowment for International Peace. Retrieved January, 13, 2016, from https://carnegie-mec.org/2014/01/29/ar-pub-54638

Haji, A. (2002). The Political Elite in Morocco, An Attempt to Define, Dissertation in Public Law. Mohammed V University, Faculty of Legal, Economic and Social Sciences, Agdal: Rabat, p.14.

Hamdan, Z. (2015). The Structure of the Hamas Speech: A Sociological Reading, Unpublished Master Thesis, Birzeit University.

Hamzawy, A., \& Den, M. (2017). Secular Political Parties in Egypt: Confrontation for Identity and Independence. Carnegie Endowment for International Peace. Retrieved April 15, 2017, from https://carnegiemec.org/2017/03/31/ar-pub-6859

Hazri, F. (2013). Religious elites in Algeria. Unpublished doctoral thesis in sociology, University of Abu Bakr Belqayd: Algeria.

Huntington, S. (1957). The Soldier and the State. New York Random- House.

Huntington, S. (1977). Political Order in Changing Societies. New Haven and London: Yale University Press.

LeKareny, I. (2007). Political Elite and Reform Issues. Democracy Magazine, Al-Ahram Institution, Cairo, (25).

Lipset, M., \& Solar, A. (1967). Elite in Latin America. Oxford University Press.

Madi, A. (2012). Civil Military Relations and Democratic Transformation. Conference on the Transformations of Democracy in the Arab World, Issam Fares Center for Lebanese Affairs, Beirut, June 28. For more information. Retrieved February 19, 2018, from http://www.abdelfattahmady.net/research/conferences-andseminars

McCoy, D., \& Eric, S. (2001). The Study of Political Elites in Federal Democracies. International Review of Sociology: Revue Internationale de Sociologie, 11(2), 247-264.

Michels, R. (1962). Political Parties: A Sociological Study of the Oligarchical Tendencies of Modern Democracy, Translated by Eden and Cedar Paul. New York: the Free Press.

Mills, W. (1956). The PoervElite. Oxford University Press, USA.

Mohammed, T. B. S. (2017). Political Reform in Jordan: Reality and Aspirations. World Affairs Journal, 180. https://doi.org/10.1177\%2F0043820018765373

Morsi, A., \& Brown, N. (2013). Al-Azhar Stepping Towards Independence and Influence in Egypt. Carnegie Endowment for International Peace. Retrieved August 11, 2017, from https://carnegiemec.org/publications/53591

Mosca, G. (1939). The Ruling Class, Edited and Revised by Arthur Livingston. New York, MC Graw-Hill book Co.

Mustafa, H. (2012). The Crisis of Arab Liberalism: The Model of Egypt. Journal of International Politics.

Prester, B., \& Altosir, L. (2014). Ideology and Ideological State Instruments. Readings, Translated by Amr Khairy. Retrieved June, 15, 2015, from https://qira2at.com/2014/11/23/

Salameh, M. T. B. (2019). Muslim brotherhood and the Jordanian state: Containment or fragmentation bets (19992018)? Asian Journal of Comparative Politics. https://doi.org/10.1177/2057891119891035

Shadouh, I. (2017). Economic Transitions and Political elites in Jordan (1989-2015), unpublished doctoral thesis, Hassan I University, Kingdom of Morocco, p. 12.

Suleiman, H. (2016). Civil Relations, Military and Democratic Transformation in Egypt after the January 25 Revolution. Arab Center for Policy Research and Research, Doha: Qatar. Retrieved July 13, 2018, from http://www.abdelfattahmady.net/research/conferences-and-seminars 
Talawi, A. (2016). Military Establishment and Management of the Media Machine in Egypt. The Egyptian Institute for Political and Strategic Studies. Retrieved August 11, 2017, from https://eipss-eg.org/wpcontent/uploads/2016/01

Torki Bani Salameh, M. (2017). Political Reform in Jordan: Reality and Aspirations. World Affairs, 180(4), 47-78. https://doi.org/10.1177/0043820018765373

Yousef, M. (2015). The Paths of Islamic Movements after Mobility: A Reading at the Fifth Conference of the Movement of Tawheed and Islah. Journal of Additions, 31-32.

Zahran, F. (2007). New Social Movements. Cairo Institute for Human Rights Studies. Retrieved June 23, 2014, from https://cihrs.org/wp-content/uploads/2011/12/

Zaki, A. M. (2016). The Deep State in Egypt: Characteristics and Pillars. Egyptian Institute for Political and Strategic Studies. Retrieved June 11, 2016, from http://www.eipss-eg.org

\section{Copyrights}

Copyright for this article is retained by the author(s), with first publication rights granted to the journal.

This is an open-access article distributed under the terms and conditions of the Creative Commons Attribution license (http://creativecommons.org/licenses/by/4.0/). 